University of Nebraska - Lincoln

DigitalCommons@University of Nebraska - Lincoln

U.S. Environmental Protection Agency Papers

U.S. Environmental Protection Agency

2010

\title{
Persistent organic pollutants in fish tissue in the mid-continental great rivers of the United States
}

Karen A. Blocksom

U.S. Environmental Protection Agency, Blocksom.karen@epa.gov

David M. Walters

U.S. Environmental Protection Agency

Terri M. Jicha

U.S. Environmental Protection Agency

James M. Lazorchak

U.S. Environmental Protection Agency

Theodore R. Angradi

U.S. Environmental Protection Agency

See next page for additional authors

Follow this and additional works at: https://digitalcommons.unl.edu/usepapapers

Part of the Civil and Environmental Engineering Commons

Blocksom, Karen A.; Walters, David M.; Jicha, Terri M.; Lazorchak, James M.; Angradi, Theodore R.; and Bolgrien, David W., "Persistent organic pollutants in fish tissue in the mid-continental great rivers of the United States" (2010). U.S. Environmental Protection Agency Papers. 96.

https://digitalcommons.unl.edu/usepapapers/96

This Article is brought to you for free and open access by the U.S. Environmental Protection Agency at DigitalCommons@University of Nebraska - Lincoln. It has been accepted for inclusion in U.S. Environmental Protection Agency Papers by an authorized administrator of DigitalCommons@University of Nebraska - Lincoln. 


\section{Authors}

Karen A. Blocksom, David M. Walters, Terri M. Jicha, James M. Lazorchak, Theodore R. Angradi, and David W. Bolgrien 


\title{
Persistent organic pollutants in fish tissue in the mid-continental great rivers of the United States
}

\author{
Karen A. Blocksom ${ }^{\text {a,* }}$, David M. Walters ${ }^{\mathrm{a}, 1}$, Terri M. Jicha ${ }^{\mathrm{b}}$, James M. Lazorchak ${ }^{\mathrm{a}}$, \\ Theodore R. Angradi ' ${ }^{\text {, David W. Bolgrien }}{ }^{\text {' }}$ \\ ${ }^{a}$ U.S. Environmental Protection Agency, National Exposure Research Laboratory, Ecological Exposure Research Division, 26 W. Martin Luther King Dr., Cincinnati, OH 45268, USA \\ ${ }^{b}$ U.S. Environmental Protection Agency, National Health and Environmental Effects Research Laboratory, Mid-Continent Ecology Division, 6201 Congdon Boulevard, Duluth, \\ MN 55804, USA
}

\section{A R T I C L E I N F O}

\section{Article history:}

Received 2 September 2009

Received in revised form 17 November 2009

Accepted 18 November 2009

Available online 8 December 2009

\section{Keywords:}

Persistent organic contaminants

Contamination indicators

Upper Mississippi River basin

Fish homogenates

\begin{abstract}
A B S T R A C T
Great rivers of the central United States (Upper Mississippi, Missouri, and Ohio rivers) are valuable economic and cultural resources, yet until recently their ecological condition has not been well quantified. In 20042005, as part of the Environmental Monitoring and Assessment Program for Great River Ecosystems (EMAPGRE), we measured legacy organochlorines (OCs) (pesticides and polychlorinated biphenyls, PCBs) and emerging compounds (polybrominated diphenyl ethers, PBDEs) in whole fish to estimate human and wildlife exposure risks from fish consumption. PCBs, PBDEs, chlordane, dieldrin and dichlorodiphenyltrichloroethane (DDT) were detected in most samples across all rivers, and hexachlorobenzene was detected in most Ohio River samples. Concentrations were highest in the Ohio River, followed by the Mississippi and Missouri Rivers, respectively. Dieldrin and PCBs posed the greatest risk to humans. Their concentrations exceeded human screening values for cancer risk in $27-54 \%$ and $16-98 \%$ of river $\mathrm{km}$, respectively. Chlordane exceeded wildlife risk values for kingfisher in 11-96\% of river km. PBDE concentrations were highest in large fish in the Missouri and Ohio Rivers (mean $>1000 \mathrm{ng} \mathrm{g}^{-1}$ lipid), with congener 47 most prevalent. OC and PBDE concentrations were positively related to fish size, lipid content, trophic guild, and proximity to urban areas. Contamination of fishes by OCs is widespread among great rivers, although exposure risks appear to be more localized and limited in scope. As an indicator of ecological condition, fish tissue contamination contributes to the overall assessment of great river ecosystems in the U.S.
\end{abstract}

Published by Elsevier B.V.

\section{Introduction}

The mid-continent great rivers of the U.S., the Upper Mississippi, Missouri, and Ohio Rivers, provide drinking and industrial water sources, serve as commercial transportation corridors, and provide recreational opportunities for millions of people (Delong, 2005; Galat et al., 2005; White et al., 2005). Intense human use of these ecosystems creates high potential for contamination of aquatic biota including fish. For example, coke plants, steel mills, chemical plants, petroleum facilities, and other heavy industries have been a fixture of the Ohio River Valley for decades. In addition, agriculture comprises a large portion of the Ohio basin, and runoff of nutrients and pesticides are common sources of pollution from tributaries (White et al., 2005). Agricultural inputs are the greatest concern for the Upper Mississippi River, but some large urban areas with a legacy of industrial contamination are also located on this part of the river (Delong,

\footnotetext{
* Corresponding author. Tel.: +1 513569 7139; fax: +1 5135697609.

E-mail address: Blocksom.karen@epa.gov (K.A. Blocksom).

${ }^{1}$ Current affiliation: U.S. Geological Survey, Fort Collins Science Center, 2150 Centre Ave, Building C, Fort Collins, CO 80526, USA.
}

2005). Primary human impacts on the Missouri River include high dams in the upper reaches, and channelization, agriculture (Galat et al., 2005), and contamination by persistent chemicals in the Lower Missouri River, owing to urban and agricultural land uses along the river (Echols et al., 2008). As a result of these land use practices and inadequate protection of water quality, persistent toxic substances have accumulated in these rivers.

Fish tissue contamination is a reliable indicator of bioaccumulation of persistent toxic substances in the environment, and has been used to estimate contaminant exposure risk to higher trophic levels, including humans and piscivorous wildlife (Lazorchak et al., 2003; Hinck et al., 2006b; Ackerman et al., 2008; Stahl et al., 2009). Several recent studies have reported on fish tissue contaminants at large scales or in large river basins (Greenfield et al., 2005; Hinck et al., 2006a,b; Ackerman et al., 2008; Schwindt et al., 2008). However, few of these employed random site selection to allow extrapolation of results to unsampled locations (e.g., Peterson et al., 2007; Harvey et al., 2008; Stahl et al., 2009).

In spite of the cultural and economic significance of these three great rivers, large-scale synoptic surveys of fish tissue contamination are lacking for these systems, and none have used a probability-based 
design that allows for the extrapolation to the entire river. Past studies of fish tissue contamination in these rivers have been more limited in scale. Many have either included only a portion of the Upper Mississippi basin or sampled only a limited number of sites in each river (Schmitt, 2002; ORSANCO, 2004; Hinck et al., 2009). Others have focused on other endpoint organisms (Cope et al., 1999) or on the Lower Mississippi River (Watanabe et al., 2003).

The U.S. Environmental Protection Agency's (USEPA) Environmental Monitoring and Assessment Program for Great River Ecosystems (EMAP-GRE) was initiated to develop and demonstrate indicators to assess the condition of great rivers in the central United States (Angradi et al., 2009). This is the first large-scale study of these rivers employing a statistically-based sampling design. The probability design allows spatially unbiased estimates of condition. In 2004 to 2005, the EMAP-GRE program collected data on a wide range of ecosystem components including biotic assemblages (e.g., fish, macroinvertebrates, algae), water chemistry, aquatic and riparian habitat, and fish tissue from the Upper Mississippi, Missouri, and Ohio rivers. Each component provides information about the condition of the resource, and fish tissue contaminants, the focus of this paper, are indicators of exposure risk for wildlife and humans to legacy contaminants. These contaminants include polychlorinated biphenyls (PCBs), and organochlorine (OC) pesticides (e.g., chlordane, dichlorodiphenyltrichloroethane (DDT), and dieldrin).

In this paper, we estimate the extent and magnitude of risk to humans and wildlife from exposure to these chemical contaminants in each river. Tissue contamination in small- and large-bodied fishes was determined to provide exposure assessments for both piscivorous wildlife and humans, respectively. Small species, such as minnows (Cyprinidae), have short life spans and are food for mammals and birds, such as American mink (Mustela vison) and Belted Kingfisher (Ceryle alcyon). Larger game species, such as catfish (Ictaluridae) and bass (Centrarchidae), are more likely to be consumed by humans. Therefore, our analysis provides both an ecological and a human health risk perspective. Flame retardants (polybrominated diphenyl ethers, PBDEs) are an important class of emerging contaminants and were measured to determine baseline tissue concentrations. Our final objective was to assess the influence of environmental factors (i.e., land uses) and fish autecology (e.g., body length and trophic guild) on tissue contaminant concentrations.

\section{Methods}

\subsection{Sampling design}

The EMAP design approach consists of the sample frame and the probability survey. The sample frame is a geographic information system (GIS) coverage of the resource to be assessed, in this case, the center line of each river derived from the National Hydrography Dataset (NHD, http://nhd.usgs.gov/index.html). The probability survey algorithm included an explicit random element in the site selection (Stevens, 1997), with spatial balance incorporated to disperse the sites and increase the representativeness of the sample (McDonald et al., 2004). Additional details describing EMAP probability designs in general are available at www.epa.gov/nheerl/arm/ designpages/design\&analysis.htm (accessed August 11, 2009). A single sample design was created for all three rivers (Angradi et al., 2009). Briefly, a sufficient number of sites were allocated to each river (Fig. 1) to insure an adequate sample size from each state's portion of a great river to estimate condition (i.e., proportion of $\mathrm{km}$ in a given condition) with a desired level of precision. This meant a minimum of 30-50 sites per state-level reporting unit per river whenever possible for this study.

The Missouri river was divided at river kilometer ( $\mathrm{rkm}$, from the mouth) 1211 (Ponca State Park, Nebraska) into an upper section consisting of a series of reservoirs and a lower section having a more natural hydrograph. The Upper Mississippi River (above the confluence with the Ohio River), was divided at rkm 327 into an upriver impounded reach, and a free-flowing unimpounded reach thence to the confluence. The Ohio River was treated as a single reach. The survey algorithm selected a single point on the river center line as defined by the NHD for each sample location. Field sampling was conducted relative to this point, and all site data accrued to this point for population estimates. As part of the probability design, each site received a weight indicating the number of rkm the site represented for population-scale estimates (Stoddard et al., 2005; see also http:// www.epa.gov/nheerl/arm accessed August 11, 2009). Weights ranged from 12.8 to $57.6 \mathrm{rkm}$ across all rivers, with an average weight of $31.1 \mathrm{rkm}$.

\subsection{Sample collection}

Fish were collected July through September 2004-2005 by day electrofishing of two separate $500 \mathrm{~m}$ reaches along a single main channel shoreline (Lazorchak et al., 2006). Composite samples for fish tissue were taken from the fish collected from one or both of these electrofishing reaches. Two samples, one of large-bodied species and one of small-bodied species, were collected for fish tissue analysis (Table S1). Large species typically represent fish targeted by recreational anglers and served as indicators of exposure of humans to contaminants in fish tissue. Smaller species represented potential prey for piscivorous wildlife and were an indicator of wildlife risk of exposure.

The procedure for sampling both large and small species was to retain similar-sized specimens (smallest individual $>75 \%$ of the length of the largest individual) of a single species from the list in Table S1 in priority order (Lazorchak et al., 2006). For small species, crews were to collect the first species on the list for which a sample of at least $50 \mathrm{~g}$ could be collected, with a total sample of the selected species of up to $400 \mathrm{~g}$. The "similar-size" rule could be violated if necessary to obtain $>50$ g. For large fish species, crews retained at least 3 and preferably 5 similar-sized specimens of a single species. If at least 3 similar-sized or same-size-class specimens were not available for any species, individuals were composited across size classes to obtain at least 3 and preferably 5 specimens of a single species. Multi-species samples were collected as a last resort. The goal of sampling was to obtain a composite sample of a single species of fish that were similar in size, according to a prioritized list of species for each size class of fish (Lazorchak et al., 2006; Table S1). However, in 17 cases (9 for large fish, 8 for small fish) it was necessary to retain a multi-species sample. In addition, a total of 65 samples exhibited larger size variation among individuals. In both cases, we retained the samples for statistical analysis, rather than discarding them altogether and losing data for those sites.

Fish were wrapped in aluminum foil, placed in a self-sealing plastic bag, and kept on ice or frozen until shipment to the laboratory. Fish were assigned to planktivore, omnivore, invertivore, generalized carnivore and piscivore trophic guilds based on preferred food of adults (Pflieger, 1975; Trautman, 1981). Omnivores consume multiple food types including detritus, algae, invertebrates and fish. Generalized carnivores are predators (e.g., freshwater drum) that feed on crayfish, other invertebrates, and fish and are distinct from piscivores (e.g., sauger) that feed almost exclusively on fish.

\subsection{Analysis of organic compounds and lipids}

Detailed methods for sample homogenization, extraction, analyses, as well as quality control procedures are provided in Supplementary data. Whole fish homogenates were analyzed for 20 pesticides (chlordane components, DDT and metabolites, aldrin, dieldrin, endosulfan I and II, endrin, heptachlor epoxide, hexachlorobenzene (HCB), lindane, and mirex), 20 polychlorinated biphenyl 


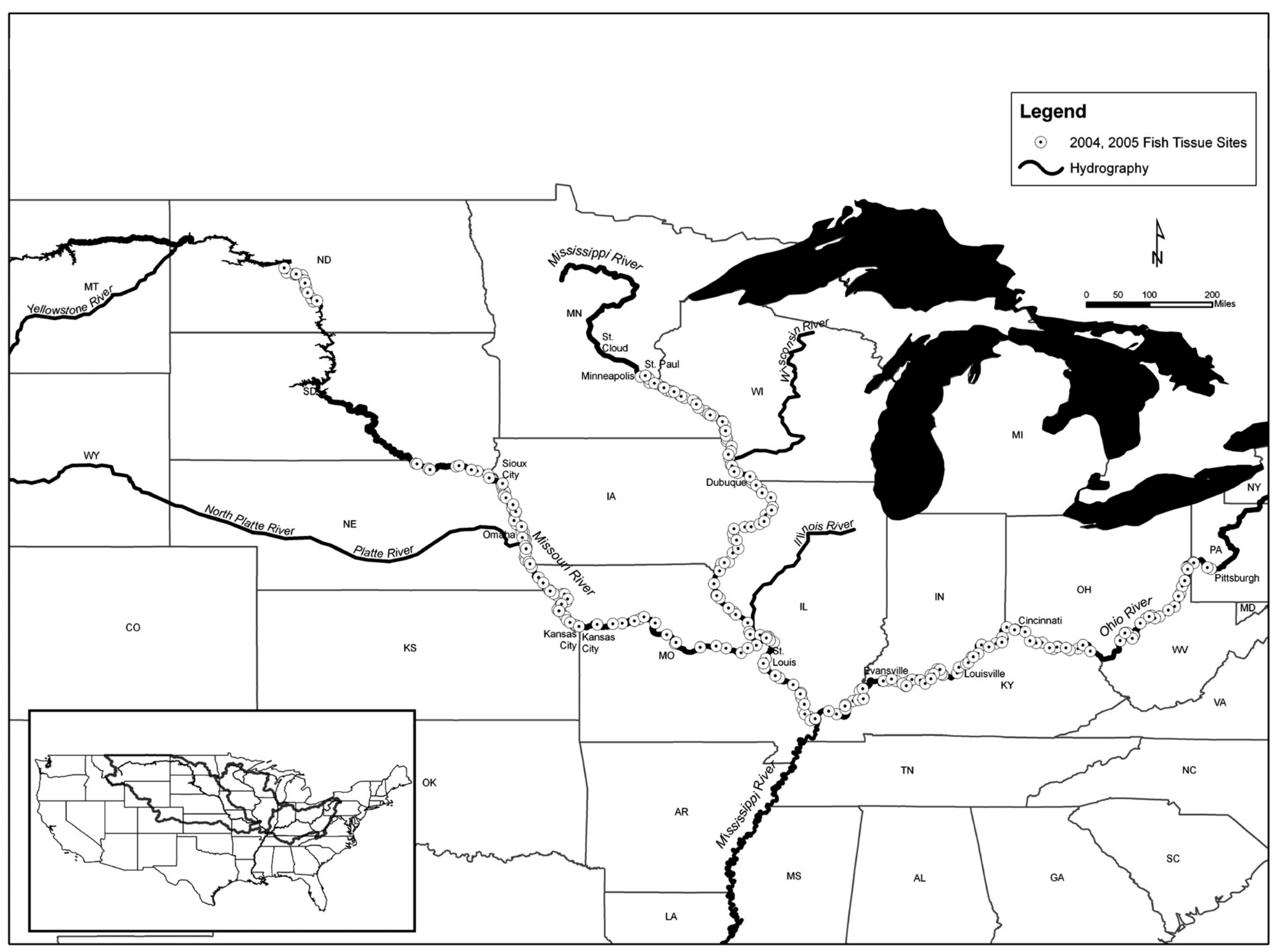

Fig. 1. Locations of probability-based sampling sites across Mississippi, Missouri, and Ohio rivers. 
(PCB) congeners, and six polybrominated diphenyl ether (PBDE) congeners (Table S2). Homogenates were mixed with anhydrous $\mathrm{Na}_{2} \mathrm{SO}_{4}$, and extracted in a Dionex ASE-200 accelerated solvent extractor using a combination of methylene chloride and hexane. A $5 \mathrm{~mL}$ aliquot of extract was removed for lipid analysis, and total percent lipid was calculated using the gravimetric method. The remaining extract was cleaned by adding acentonitrile, freezing and centrifuging to remove lipids and then eluting through an alumina- $\mathrm{N}$ (level III) column with hexane. Analysis for organic compounds was by gas chromatography-electron capture detection (GC-ECD) following EPA method 508.1. Detection limits are shown in Table S2. Laboratory fortified blanks (LFBs) were analyzed twice per batch to assess recovery and reproducibility (the relative percent difference [RPD] between two LFBs). Recovery averaged 93.5\% ( $\pm 17.6 \%$ SD) and RPD averaged $8.9 \%( \pm 9.2 \% \mathrm{SD})$ among organic compounds (Table S2).

\subsection{Statistical analysis}

Data from all samples were combined into a single data set each for small and large fish, encompassing all specimens in that size group (Table S1). Statistical analyses were performed for total PCBs (sum of 20 congeners [Table S2]), total chlordane (sum of cis-chlordane, trans-chlordane, trans-nonachlor, cis-nonachlor, and oxychlordane), total DDT ( sum of all forms of dichlorodiphenyldichloroethane (DDD), dichlorodiphenyldichloroethylene (DDE), and DDT), total PBDEs (sum of 6 congeners [Table S2]), aldrin, dieldrin, endrin, endosulfan (I and II), heptachlor epoxide, hexachlorobenzene (HCB), lindane, and mirex. Values below the detection limit were set to zero for summing across congeners or breakdown products. However, if all congeners or breakdown products were below the detection limit, the total was set to one half the detection limit for subsequent calculations.

Organic contaminant wildlife values (WVs) and human screening values (SVs) estimate environmental risks of fish consumption for sensitive wildlife and human populations (e.g., children and women of child bearing age). Wildlife risk values (WVs) for the consumption of small species were obtained for American mink and Belted Kingfisher (hereafter mink and kingfisher) from Lazorchak et al. (2003). They were based primarily on USEPA guidance (USEPA, 1995) that represented an EPA rulemaking involving extensive peer review and a public comment response process. Thus, for Agency consistency, Lazorchak et al. (2003) is viewed as an extension of this guidance from water to fish tissue. Both mink and kingfisher are widely distributed throughout the sampling area and are realistic models of exposure. Both species are piscivorous and expected to experience the highest exposures to bioaccumulative contaminants through the aquatic food web, rather than through water ingestion (Lazorchak et al., 2003). Wildlife values were not available for many organochlorine pesticides, including aldrin, endosulfan, heptachlor epoxide, $\mathrm{HCB}$, lindane, or mirex.

Human health screening values (SVs) for consumption of large species were calculated according to USEPA guidance (USEPA, 2000), and all contaminants were treated as carcinogens except endrin, endosulfan, and mirex. We assumed a human body weight of $70 \mathrm{~kg}$, daily consumption rate of $0.0175 \mathrm{~kg}$ fish $\mathrm{day}^{-1}$, and an acceptable lifetime risk of cancer of $10^{-5}$. Oral reference dose (RfD) and oral cancer slope factor (CSF) values for non-carcinogenic and carcinogenic organics, respectively, were obtained from the U.S. EPA's Integrated Risk Information System (IRIS, http://www.epa.gov/iris/ index.html, accessed June 11, 2008). Whole fish were analyzed rather than a typical human food portion (filets), so we followed Ackerman et al. (2008) and increased SVs for organics by $32 \%$ to account for the lipophilic nature of these contaminants and the reduction in exposure expected from eating muscle tissue compared to whole fish (Amrhein et al., 1999; USEPA, 2000).

All WVs and adjusted SVs are provided in Table S3. However there are no screening values for PBDEs because they are emerging contaminants. For this contaminant, as well as all other contaminants, we determined the rate of detection among samples by river and river section. We did not assess the Upper Missouri River or Unimpounded Mississippi River separately due to small sample sizes for fish tissue (Table S4). For comparison with other studies, PBDE values were lipid-normalized for individual congeners before summing. Our use of a probability-based design allowed us to extrapolate our results to an entire river or reach and to estimate the variability around estimates of contamination extent (www.epa.gov/nheerl/arm/analysispages/ monitanalysisinfo.htm, accessed August 11, 2009). We used sample site weights derived from the probability design to estimate the extent of each river or river section having fishes with contaminant concentrations (1) above the detection limit and (2) above WVs or SVs (based on wet weight concentrations).

We examined associations of contaminant concentrations with developed land cover. Longitudinal plots were constructed by river and fish size, and major tributaries and cities were noted along each river for context. Linear regression analysis was performed to identify associations between developed land use and organics while accounting for fish ecological traits. Only those organics that could be transformed to approximate normality were modeled on the following explanatory variables: percent lipids, mean fish length, fish trophic guild (e.g., piscivore; treated as a 0/1 dummy variable, Table S1), percentage developed land use (sum of National Land Cover Database (NLCD) categories 21-24) in catchments intersecting with the river within a $50 \mathrm{~km}$ network upstream of the site, and percentage developed land use within a $10 \mathrm{~km}$ upstream network (Angradi et al., 2009). Rather than lipid-normalizing contaminant concentrations for regressions, we treated percent lipids as a covariate based on the work of Hebert and Keenleyside (1995). For the purposes of analysis carnivores and piscivores were grouped together, as were omnivores and invertivores. Best subsets regression was performed in SAS v. 9.1 (SAS Institute, Cary, North Carolina), based on Mallow's $C_{\mathrm{p}}$ statistic (Myers, 1990; Neter et al., 1996). This meant that some models included predictors that were not significant but led to a lower $C_{\mathrm{p}}$ value relative to the number of variables in the model. Contaminants were modeled separately for each river and fish size. Residuals were examined using normal probability plots and plots against predicted values.

\section{Results}

\subsection{Extent of contaminants}

Several contaminants were rarely detected and/or were rarely above wildlife and human health screening values (Table S4). Aldrin, endrin, mirex, lindane, and endosulfan were detected in $<10 \%$ of samples in any given river or section, and none occurred above the SV. Although heptachlor epoxide and HCB were detected more commonly across rivers, HCB only occurred once over the adjusted SV and heptachlor epoxide never did. Thus, all of these contaminants were excluded from further analyses. PCBs, PBDEs, and DDT were detected in nearly all samples of both large and small fish (Table S4). Dieldrin and chlordane were more commonly detected in the Ohio River overall $(>92 \%$ of $\mathrm{rkm})$ than in other rivers in the study $(\sim 52-81 \%$ of $\mathrm{rkm})$, although these contaminants were detected in all 16 samples from the Unimpounded Mississippi. Contaminants posing the greatest risk to human consumption were PCBs and dieldrin (Fig. 2). Extent of rkm (among rivers) with fish tissue above human SV was 16-94\% for PCBs and 27-54\% for dieldrin. Chlordane posed the greatest risk to kingfisher, with 11-85\% of the great rivers above the kingfisher WV. PCBs posed the greatest risk to mink (21\% of rkm in the Ohio River), but the extent of risk was low compared to that for humans. The Ohio River had the largest extent of rkm with chlordane, DDT, and total PCB concentrations greater than SVs and WVs, whereas the Missouri River had the largest extent of dieldrin above the SV and the second largest 


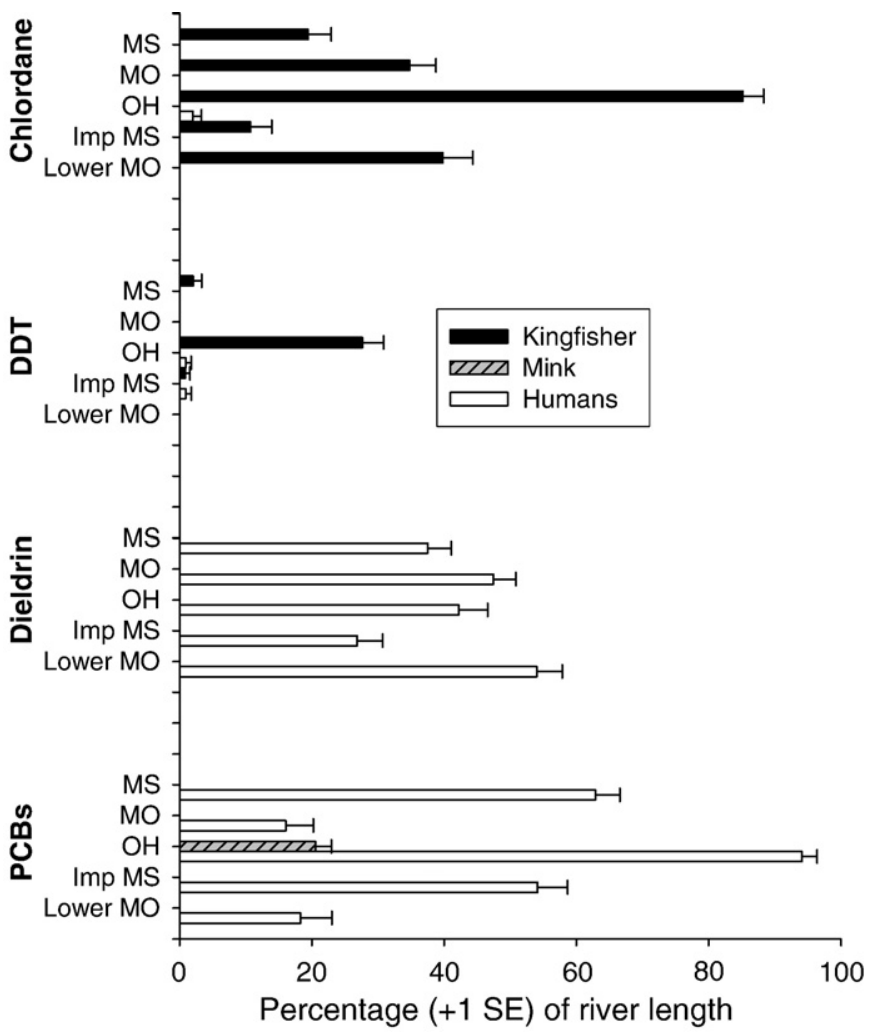

Fig. 2. Extent of contaminants in levels above wildlife and human health screening values.

extent of chlordane above the WV (Fig. 2). The percentage of rkm with total PCBs above the SV was second highest in the Mississippi River.

Fish tissue contaminant concentrations varied widely across rivers and sometimes between sections within rivers (Table 1). Many peaks in contaminant levels of large fish were associated with larger cities or confluences with larger tributaries (Fig. 3). The patterns observed for large fish generally were followed by small fish (Fig. 4), although small fish exhibited lower levels of all contaminants except dieldrin. Organic compounds were highest just downstream of MinneapolisSt. Paul (Twin Cities, MN) and St. Louis on the Mississippi River; Kansas City on the Missouri River; and near Pittsburgh, Louisville, and Evansville on the Ohio River. In some cases, there were no obvious sources of higher levels of contaminants, although information about some small tributaries was limited. The Ohio River had the highest average concentrations for all major contaminants for small fish and for all but dieldrin in large fish. The Missouri River had the second highest average concentration of chlordane and PBDEs, whereas the Mississippi River typically had higher PCBs than the Missouri (Table 1). The lipid-normalized average concentrations showed similar patterns across rivers and were always higher in large fish than small fish in a given river or river section (Table S5).

Not all contaminants were modeled with regression for all rivers, as chlordane and dieldrin were only common enough in the Ohio River. DDT and PBDEs were modeled in all rivers for both fish sizes, and PCBs were modeled in all combinations except small fish in the Missouri River. The regressions for the Ohio River explained the most variation, and those for large fish in the Missouri explained the least (Table 2). Overall, concentrations tended to be higher in larger, more lipid-rich fish from higher-level trophic guilds (i.e., piscivores and carnivores). This finding was consistent with biomagnification of these persistent compounds through food webs. Higher concentrations were also associated with a higher percent developed land use in the $50 \mathrm{~km}$ network with a few exceptions. This land use varied from 4-82\% in the Mississippi River, 3-50\% in the Missouri, and 3-58\% in the Ohio. Only dieldrin and DDT concentrations in fish from the Ohio River were poorly associated with developed land cover.

The longitudinal pattern of total PBDE concentration was similar to that for PCBs in each river, regardless of fish size. For example, Spearman rank correlations between PCBs and PBDEs in large fish were $0.69,0.82$, and 0.84 in the Mississippi, Missouri, and Ohio rivers, respectively.

\subsection{PBDE concentrations}

The mean concentrations of PBDEs were much lower and less variable in the Mississippi than in other rivers, but in all rivers and sections, the mean lipid-normalized concentrations for large fish were two to three times those for small fish (Fig. 5, Table S5). The maximum concentrations of total PBDEs in small fish were 704, 2914, and $2266 \mathrm{ng} \mathrm{g}^{-1}$ lipid in the Mississippi, Missouri, and Ohio rivers, respectively. Maximum values observed for large fish were 3030, 87121, and $16366 \mathrm{ng} \mathrm{g}^{-1}$ lipid, respectively. PBDE 47 predominated in both large and small fish, followed by PBDEs 100 and 99 in small and large fish, respectively (Fig. 6).

\section{Discussion}

\subsection{Extent of contamination}

The Ohio River is known to have a PCB gradient, with higher levels upstream related to past industrial applications (Jeff Thomas, Ohio River Valley Water Sanitation Commission (ORSANCO), pers. comm.). Although levels of PCBs and organochlorines have been declining since the late 1980s (Jeff Thomas, ORSANCO, pers. comm.), the Ohio River still typically had higher concentrations for all contaminants except dieldrin, which was similar across systems (Table 1). Given its legacy of industrial pollution in its upper reaches and heavy agricultural land use in the lower basin, we had expected the concentrations of PCBs and organochlorine pesticides to be highest in the Ohio River (Galat et al., 2005). The relatively high occurrences

Table 1

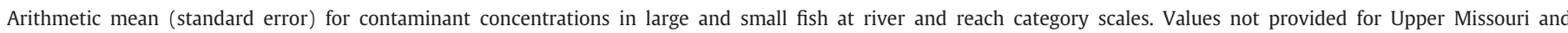

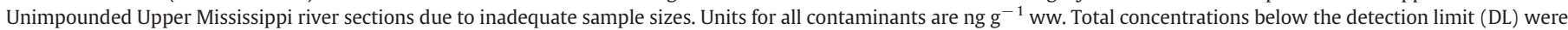
set at one half the DL for subsequent calculations. Abbreviations are as follows: Missouri (MO), Mississippi (MS), and Ohio (OH).

\begin{tabular}{|c|c|c|c|c|c|c|c|}
\hline Fish size & River/section & Chlordane & Dieldrin & DDT & PBDEs & PCBs & No. sites \\
\hline \multirow[t]{5}{*}{ Large } & Upper MS & $6.60(0.63)$ & $3.82(0.33)$ & $11.16(0.60)$ & $12.50(1.07)$ & $42.18(2.64)$ & 94 \\
\hline & Impounded MS & $3.69(0.41)$ & $3.02(0.30)$ & $9.66(0.59)$ & $8.23(0.68)$ & $36.70(2.38)$ & 78 \\
\hline & MO & $7.00(0.84)$ & $4.60(0.47)$ & $8.18(1.15)$ & $19.50(1.70)$ & $11.36(1.38)$ & 96 \\
\hline & Lower MO & $7.91(0.95)$ & $5.17(0.53)$ & $9.04(1.30)$ & $21.81(1.94)$ & $12.71(1.57)$ & 82 \\
\hline & $\mathrm{OH}$ & $23.77(2.53)$ & $4.12(0.36)$ & $18.32(2.64)$ & $45.66(6.69)$ & $123.12(12.63)$ & 90 \\
\hline \multirow[t]{5}{*}{ Small } & Upper MS & $2.31(0.23)$ & $3.10(0.18)$ & $6.57(0.37)$ & $5.31(0.39)$ & $19.77(0.93)$ & 93 \\
\hline & Impounded MS & $1.39(0.14)$ & $2.66(0.11)$ & $6.54(0.37)$ & $4.43(0.28)$ & $19.67(0.84)$ & 78 \\
\hline & MO & $4.54(0.40)$ & $3.19(0.25)$ & $5.47(0.38)$ & $12.72(2.08)$ & $7.41(0.74)$ & 92 \\
\hline & Lower MO & $5.14(0.46)$ & $3.59(0.29)$ & $6.14(0.43)$ & $14.18(2.39)$ & $8.43(0.85)$ & 78 \\
\hline & $\mathrm{OH}$ & $19.41(0.73)$ & $4.75(0.32)$ & $15.60(0.62)$ & $28.10(1.47)$ & $90.31(3.66)$ & 89 \\
\hline
\end{tabular}




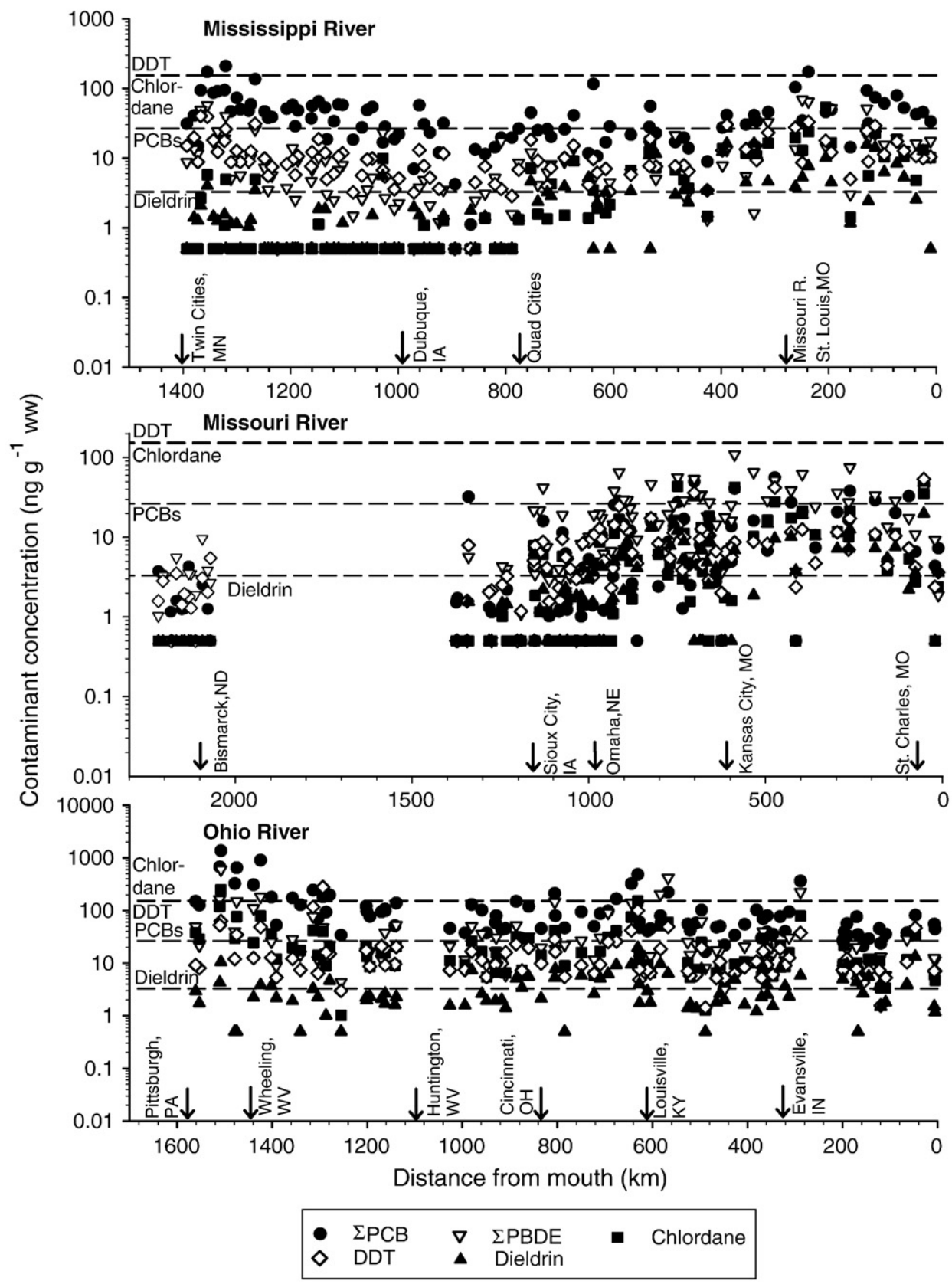

Fig. 3. Longitudinal profiles of contaminants ( $\mathrm{ng} \mathrm{g}^{-1}$ wet weight) in large fish in the Upper Mississippi, Missouri, and Ohio Rivers. Note different scales on Y-axes for illustration purposes. Major cities and other points of interest are shown for spatial context. Reference lines represent human screening values. The term "Quad Cities" refers to the towns of Davenport and Bettendorf, IA, and Moline, Rock Island, and East Moline, IL. MNRR is the Missouri National Recreational River. The gap in the Missouri River plot represents 6 reservoirs that were excluded from the study. Non-detects were set at half the detection limit.

of dieldrin and PBDEs in the Missouri River were linked to metropolitan areas along the river and largely concentrated in the lower section (Figs. 3 and 4).

The legacy contaminants posing the greatest exposure risk differ for wildlife and humans but are somewhat consistent across rivers (Fig. 2). For humans, the greatest risk of exposure is posed by PCBs and dieldrin. Wildlife risk is highest for the kingfisher primarily due to chlordane. These risks occur throughout the Ohio River but were generally limited to the lower section of the Missouri River. The greatest risks for both humans and kingfishers in the Upper Mississippi River occur in the lower part of the impounded section. We cannot assess exposure risk for PBDEs due the lack of WVs and SVs for these contaminants.

The association between PBDEs and PCBs in fish tissue was particularly strong in the Ohio and Missouri rivers. This is not surprising because the two contaminants are structurally similar and known to persist in the environment. A similar association between PCBs and PBDEs was observed in Lake Michigan salmonids (Manchester-Neesvig et al., 2001), implying similar prevalence between the two contaminants in that system. However, the strong co-occurrence of these two contaminant classes in the great rivers in this study does not necessarily imply similar sources and requires further research to determine the precise nature and cause of this association.

Obviously, there is the potential for species differences in contaminant load, particularly when species are from different trophic guilds. We did not assess species difference in contaminant concentrations because few species had large enough sample sizes to allow for individual analyses. In addition, and more importantly, this study was not designed to assess differences in contaminant concentrations among species, and observed differences would be 

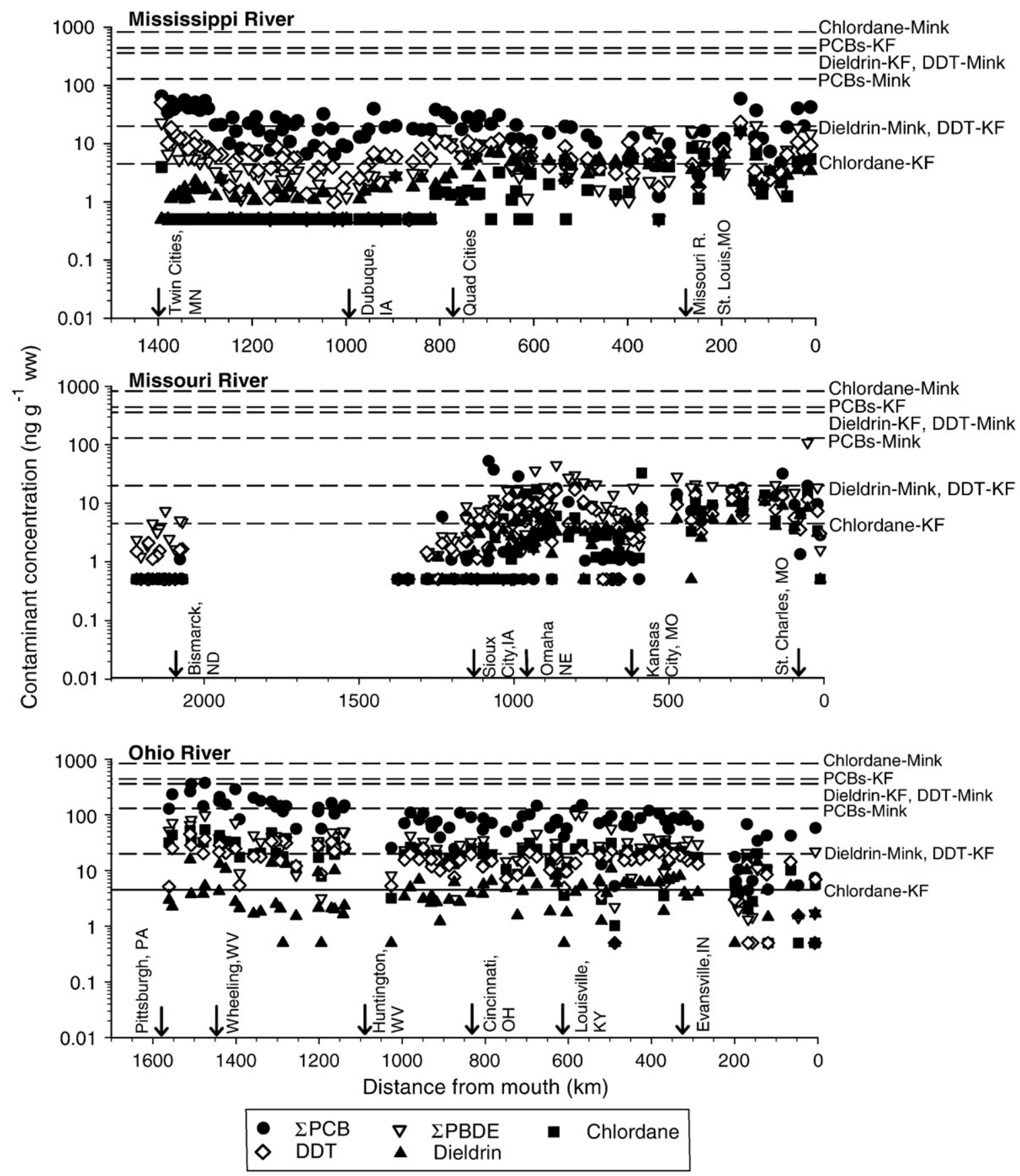

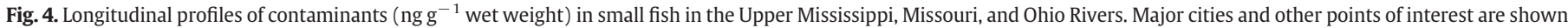

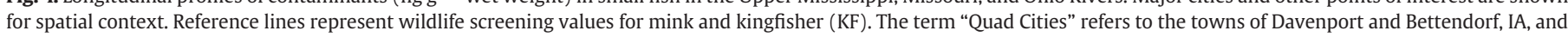

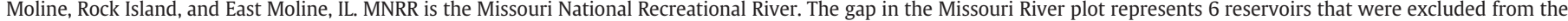
study. Non-detects were set at half the detection limit.

confounded with site or river differences, and could never be strictly attributed to species. Finally, the goal of this study was to develop a composite picture of the contaminant exposure at the scale of an entire reach or river, so by using a prioritized target species list, we obtain a more representative sample across sites.

\subsection{Comparisons with other studies}

The National Contaminant Biomonitoring Program measured legacy organochlorines in whole fishes from U.S. waters (primarily major rivers and the Great Lakes) between the mid-1970s and mid1980s (Schmitt et al., 1999). Concentrations of many contaminants declined substantially (usually by $\sim 50 \%$ ) over this period as a direct result of regulatory action, and our data suggest that this trend toward lower contaminant levels is ongoing for some compounds. Concentrations of DDT in great rivers fish averaged $8-18 \mathrm{ng} \mathrm{g}^{-1}$ among rivers, roughly one order of magnitude lower than the national average (geometric mean) of $110 \mathrm{ng} \mathrm{g}^{-1}$ in 1986 (Schmitt et al., 1999). Mean total chlordane concentrations were also much lower in great rivers in 2004-2005 (8-24 $\mathrm{ng} \mathrm{g}^{-1}$ among rivers) than in 1986 $\left(56 \mathrm{ng} \mathrm{g}^{-1}\right)$, whereas dieldrin levels were largely unchanged and generally low (mean $8 \mathrm{ng} \mathrm{g}^{-1}$ in 1986 versus $3-5 \mathrm{ng} \mathrm{g}^{-1}$ among great rivers).

Directly comparing concentrations observed in this study with other probability studies is complicated because data are presented in varying formats. Only the maximum concentrations are provided for 
Table 2

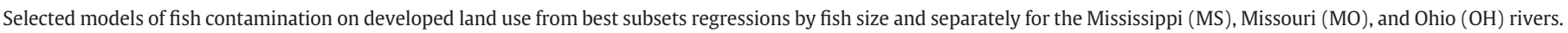

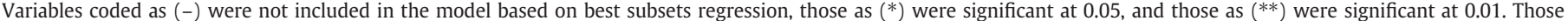
variables left blank were selected for the model but not significant at 0.05 .

\begin{tabular}{|c|c|c|c|c|c|c|c|c|c|}
\hline $\begin{array}{l}\text { Group } \\
\text { (river, fish size) }\end{array}$ & $\begin{array}{l}\text { Variable } \\
\text { (transform indicated) }\end{array}$ & $N$ & Guild & Mean length & \% lipids & Log 50 km network & Log $10 \mathrm{~km}$ network & Adj. $R^{2}$ & Mallow's $C_{\mathrm{p}}$ \\
\hline \multirow[t]{3}{*}{ MS large } & Log DDT & 119 & $* *$ & $* *$ & $* *$ & $* *$ & & 0.29 & 6.0 \\
\hline & Log PCB & 119 & $* *$ & $* *$ & - & $*$ & - & 0.23 & 3.6 \\
\hline & Log PBDE & 119 & - & $* *$ & - & $* *$ & - & 0.22 & 1.3 \\
\hline \multirow[t]{3}{*}{ MS small } & Log DDT & 118 & & - & $* *$ & $* *$ & - & 0.32 & 3.0 \\
\hline & Sqrt PCB & 118 & $* *$ & - & $* *$ & $* *$ & - & 0.33 & 2.1 \\
\hline & Log PBDE & 118 & - & - & $* *$ & $* *$ & - & 0.25 & 2.3 \\
\hline \multirow[t]{3}{*}{ MO large } & Log DDT & 112 & - & - & - & $* *$ & - & 0.14 & 0.8 \\
\hline & Log PCB & 112 & - & - & - & $* *$ & - & 0.07 & 1.5 \\
\hline & Log PBDE & 112 & $*$ & - & & $* *$ & - & 0.21 & 3.6 \\
\hline \multirow[t]{2}{*}{ MO small } & Log DDT & 92 & - & $*$ & - & $* *$ & - & 0.21 & 1.7 \\
\hline & Log PBDE & 92 & $* *$ & - & & $* *$ & - & 0.28 & 2.8 \\
\hline \multirow[t]{5}{*}{ OH large } & Log DDT & 102 & $*$ & $* *$ & $* *$ & & & 0.46 & 6.0 \\
\hline & Log PCB & 102 & $*$ & $* *$ & $* *$ & $* *$ & - & 0.44 & 4.4 \\
\hline & Log PBDE & 102 & $*$ & $* *$ & & $* *$ & - & 0.51 & 4.4 \\
\hline & Log dieldrin & 102 & - & - & $* *$ & - & - & 0.22 & -0.2 \\
\hline & Log chlordane & 102 & $*$ & $* *$ & $* *$ & $* *$ & - & 0.52 & 4.0 \\
\hline \multirow[t]{5}{*}{$\mathrm{OH}$ small } & Sqrt DDT & 110 & $* *$ & & $* *$ & & & 0.58 & 6.0 \\
\hline & Log PCB & 110 & $* *$ & $*$ & - & $* *$ & - & 0.57 & 3.1 \\
\hline & Log PBDE & 110 & $* *$ & & & $* *$ & - & 0.68 & 4.1 \\
\hline & Sqrt dieldrin & 110 & $* *$ & $* *$ & - & - & - & 0.47 & 1.4 \\
\hline & Sqrt chlordane & 111 & $* *$ & - & $* *$ & $* *$ & - & 0.61 & 2.6 \\
\hline
\end{tabular}

EMAP-National Coastal Assessment (NCA) (Harvey et al., 2008), and they were comparable for PCBs and considerably higher for DDT than maximum values observed here. When lipid-normalized, average organochlorine concentrations in great rivers (Table S5) were similar to those measured in MAH fish (Lazorchak et al., 2003). However, it is not clear whether the magnitudes of normalized values are particularly high because screening values are not based on lipidnormalized values.

We can, however, compare our estimates of exposure to contaminants with those of other probability-based studies. For example, PCBs generally pose the greatest risk to human health in U.S. estuaries, exceeding SVs in approximately $30 \%$ of coastal waters (Harvey et al., 2008). Although area and length estimates are not directly comparable, in great rivers, the extent of risk was much greater for PCBs (up to $98 \%$ of river length) compared with coastal

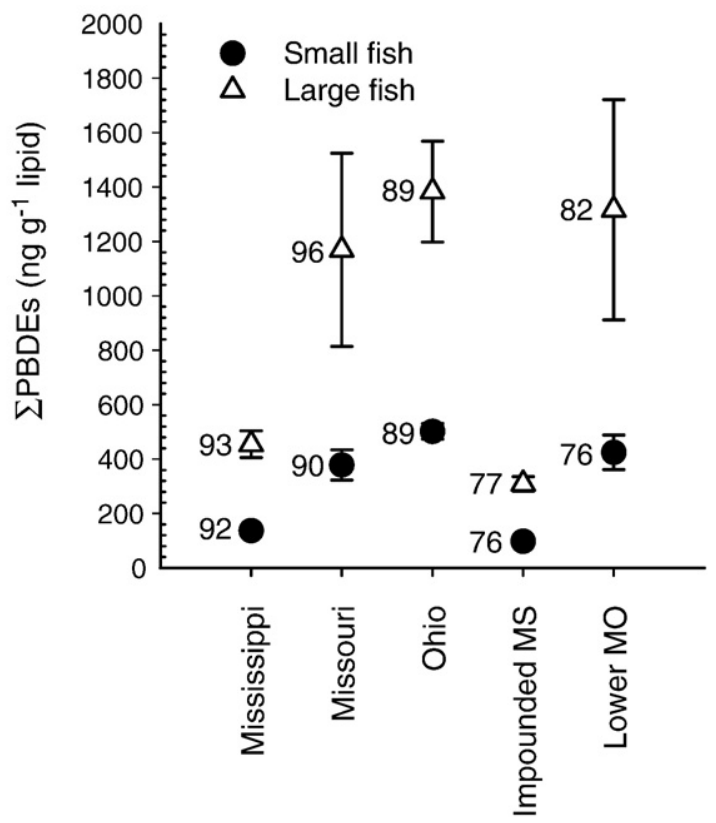

Fig. 5. Mean $(+/-1 \mathrm{SE})$ concentration of total PBDEs by fish size, river and section. Numbers next to symbols represent sample sizes.

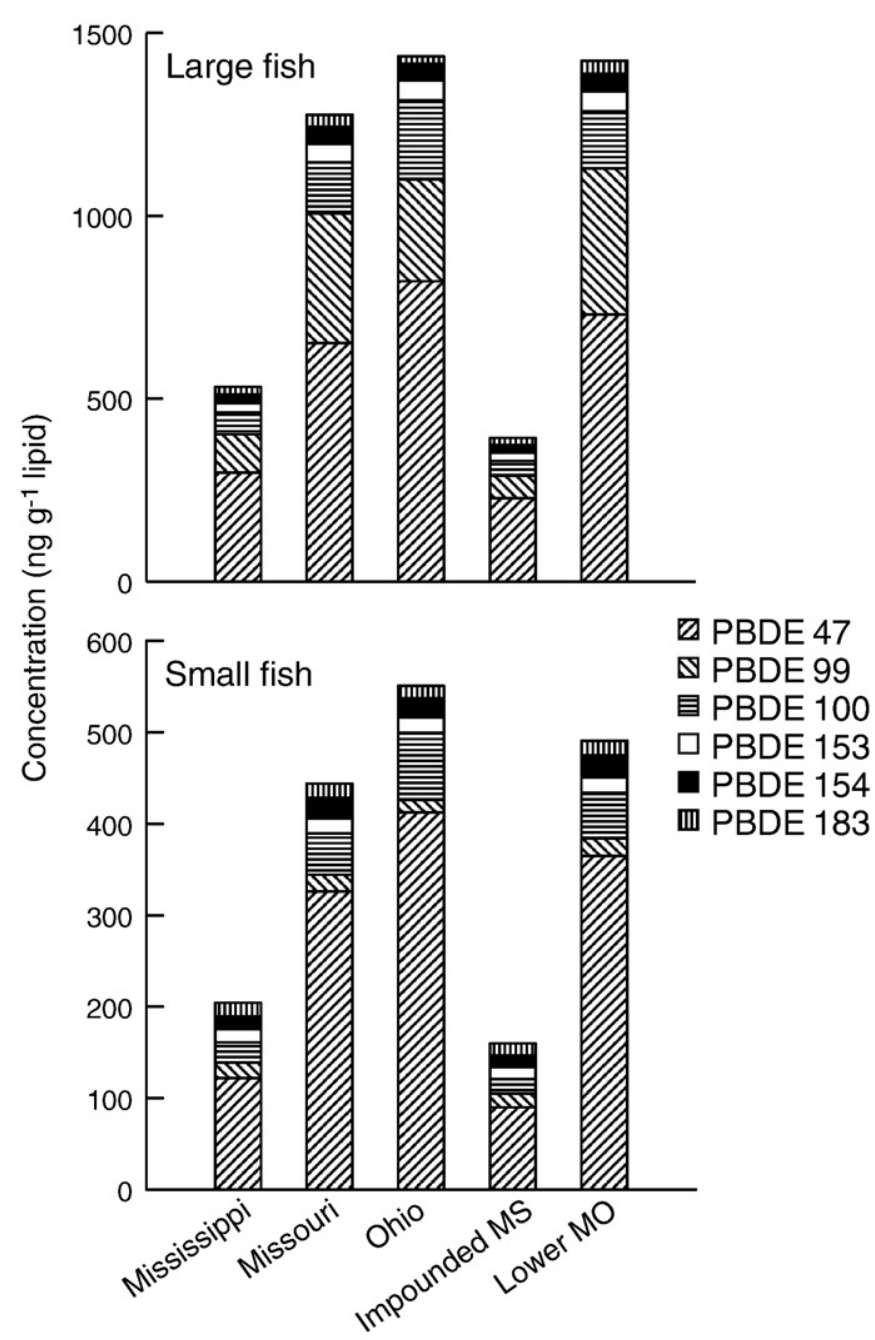

Fig. 6. Average distribution of PBDE congeners by river and section for large and small fish. 
waters ( $\sim 12-43 \%$ by area). Likewise, dieldrin poses widespread risk to human health in the great rivers of this study (26-54\% of length among rivers), but was rarely detected above SVs in estuaries (Harvey et al., 2008). In fact, Harvey et al. (2008) did not adjust SVs to account for using whole fish rather than filets as we did, so the discrepancy between estuaries and great rivers is probably greater than estimated. In terms of wildlife risk, comparable results for organic compounds were only available for Mid-Atlantic highland (MAH) streams of the eastern U.S. (Lazorchak et al., 2003). The extent above the WV for kingfisher was low and similar between MAH streams and great rivers for PCBs and dieldrin, but chlordane risk was more widespread in the Ohio River (85\% of river length) compared with Appalachian streams ( $40 \%$ of stream length). The extent of DDT risk was nearly twice as great in the Ohio River than in Appalachian streams ( $15 \%)$.

More general comparisons with other river studies lacking a probability-based design vary widely. In samples collected from large rivers across the U.S. (Hinck et al., 2008) median total PCB and dieldrin concentrations were much higher (64-110 $\mathrm{ng} \mathrm{g}^{-1}$ ww and $5 \mathrm{ng} \mathrm{g}^{-1}$ ww across species, respectively) than the mean values found in this study. In the Yukon River, Alaska, the sums of PCBs, chlordane, and some forms of DDT were similar to mean values in this study (21-87, 0.7-10.3, and 13-14 $\mathrm{ng} \mathrm{g}^{-1} \mathrm{ww}$, respectively), whereas dieldrin values were lower (0.2-0.6 ng g ${ }^{-1}$ ww) (Hinck et al., 2006b). Fish tissue concentrations of PCBs, chlordane, and dieldrin from the Columbia River were comparable to those found in the Ohio River, but DDE alone tended toward higher values than found in this study (Hinck et al., 2006a). Maximum observed concentrations of total DDT in the Willamette River in Oregon were nearly double those in the Ohio River, although PCBs and dieldrin were comparable between the two studies (Sethajintanin et al., 2004). In contrast, samples from the River Nestos in Greece had much lower concentrations for PCBs, DDT, and chlordanes on average than observed in this study, although the data from Greece were based only on fish muscle tissue (Christoforidis et al., 2008).

\subsection{PBDE concentrations}

PBDE 47 was the dominant congener followed by either PBDE 99 or 100, similar to findings reported for other U.S. systems (Anderson and MacRae, 2006; Brown et al., 2006; Xia et al., 2008). Mean ¿PBDEs concentrations in large great-river fish were much higher than those found in the Hudson River (Xia et al., 2008), the Detroit River (Rice et al., 2002), or the California coast (Brown et al., 2006), but were similar to those in fish from the Penobscot River in Maine (Anderson and MacRae, 2006), or the Des Plaines River downstream of Joliet, IL (Rice et al., 2002).

\section{Conclusions}

Fish tissue contaminants in all three rivers were observed to a greater extent and in higher than expected levels, given that manufacture or use of these organochlorine pesticides and PCBs has been banned in the U.S. for at least two decades (http://www.epa.gov/ pbt/pubs/cheminfo.htm, accessed 17 December 2008). Dieldrin, DDT, chlordane, and PCBs all bioaccumulate in the environment due to slow degradation rates and high lipid solubilities (Newman and Unger, 2003). The associations of these contaminants with developed land cover suggest that past uses of pesticides in residential areas and of PCBs in industrial applications remain detectable in fish today, and present ongoing exposure risks to both wildlife and humans. However, some of these contaminants are still in use in other parts of the world, and atmospheric deposition may also contribute to current exposure levels.

The widespread occurrence of PBDEs across all rivers and their bioaccumulative nature as indicated by higher concentrations in large fish confirms the importance of these compounds as emerging contaminants. PBDEs bioaccumulate, and they have been identified as potential endocrine disruptors in the environment (Rahman et al., 2001; Hale et al., 2003). Recent work has shown that a metabolite of BDE 47 in particular is toxic to both embryo and adult zebrafish (van Boxtel et al., 2008). The association between PBDE and PCB concentrations in fish suggests a possible relationship between the two in terms of sources of these contaminants, whether historical or current. Regardless of source, the PBDE values observed in this study provide a valuable baseline for future comparison and assessment.

The information provided by organic contaminant levels in fish tissue supports a large-scale multi-indicator perspective on ecosystem condition in the mid-continent great rivers of the U.S. On its own, fish tissue contamination as translated to wildlife and human health risk only provides a small snapshot of legacy and emerging contaminants in these systems. In combination with other indicators, however, it becomes an integral part of the larger picture of ecosystem health as a whole.

\section{Acknowledgements}

We thank the numerous field crews that collected samples, data specialists who managed the information, and laboratory personnel that processed the samples. We thank Brian Hill, Jo Ellen Hinck, and Jeff Thomas for helpful comments and suggestions on an earlier draft of this paper. The United States Environmental Protection Agency through its Office of Research and Development funded and managed the research described herein. It has been subjected to the Agency's administrative review and approved for publication. Mention of trade names or commercial products does not constitute endorsement or recommendation for use.

\section{Appendix A. Supplementary data}

Supplementary data associated with this article can be found, in the online version, at doi:10.1016/j.scitotenv.2009.11.040.

\section{References}

Ackerman LK, Schwindt AR, Massey Simonich SL, Koch DC, Blett TF, Schreck CB, et al. Atmospherically deposited PBDEs, pesticides, PCBs, and PAHs in western U.S. national park fish: concentrations and consumption guidelines. Environ Sci Technol 2008:42:2334-41.

Amrhein JF, Stow CA, Wible C. Whole-fish versus filet polychorinated-bipheny concentrations: an analysis using classification and regression tree models. Environ Toxicol Chem 1999:18:1817-23.

Anderson TD, MacRae JD. Polybrominated diphenyl ethers in fish and wastewater samples from an area of the Penobscot River in central Maine. Chemosphere 2006;62:1153-60.

Angradi TR, Bolgrien DW, Jicha TM, Pearson MS, Hill BH, Taylor DL, et al. A bioassessment approach for mid-continent great rivers: the upper Mississippi, Missouri, and Ohio (USA). Environ Monit Assess 2009;152:425-42.

Brown FK, Winkler J, Visita P, Dhaliwal J, Petreas M. Levels of PBDEs, PCDDs, PCDFs, and coplanar PCBs in edible fish from California coastal waters. Chemosphere 2006;64:276-86.

Christoforidis A, Stamatis N, Schmeider K, Tsachalidis E. Organochlorine and mercury contamination in fish tissues from the River Nestos, Greece. Chemosphere 2008;70:694-702

Cope WG, Bartsch MR, Rada RG, Balogh SJ, Rupprecht JE, Young RD, et al. Bioassessment of mercury, cadmium, polychlorinated biphenyls, and pesticides in the Upper Mississippi River with zebra mussels (Dreissena polymorpha). Environ Sci Technol 1999;33:4385-90.

Delong MD. Upper Mississippi River basin. In: Benke AC, Cushing CE, editors. Rivers of North America. Burlington, Massachusetts: Elsevier Academic Press; 2005 p. 327-73.

Echols KR, Brumbaugh WG, Orazio CE, May TW, Poulton BC, Peterman PH. Distribution of pesticides, PAHs, PCBs, and bioavailable metals in depositional sediments of the Lower Missouri River, USA. Arch Environ Contam Toxicol 2008;55:161-72.

Galat DL, Berry Jr CR, Peters EJ, White RG. Missouri River basin. In: Benke AC, Cushing CE, editors. Rivers of North America. Burlington, Massachusetts: Elsevier Academic Press; 2005. p. 427-68.

Greenfield BK, Davis JA, Fairey R, Roberts C, Crane D, Ichikawa G. Seasonal, interannual, and long-term variation in sport fish contamination, San Francisco Bay. Sci Total Environ 2005;336:25-43. 
Hale RC, Alaee M, Manchester-Neesvig JB, Stapleton HM, Ikonomou MG. Polybrominated diphenyl ether flame retardants in the North American environment. Environ Int 2003;29:771-9.

Harvey J, Harwell L, Summers JK. Contaminant concentrations in whole-body fish and shellfish from US estuaries. Environ Monit Assess 2008;137:403-12.

Hebert CE, Keenleyside KA. To normalize or not to normalize? Fat is the question. Environ Sci Technol 1995;14:801-7.

Hinck JE, Schmitt CJ, Blazer VS, Denslow ND, Bartish TM, Anderson PJ, et al. Environmental contaminants and biomarker responses in fish from the Columbia River and its tributaries: spatial and temporal trends. Sci Total Environ 2006a;366 549-78.

Hinck JE, Schmitt CJ, Echols KR, May TW, Orazio CE, Tillitt DE. Environmental contaminants in fish and their associated risk to piscivorous wildlife in the Yukon River Basin, Alaska. Arch Environ Contam Toxicol 2006b;51:661-72.

Hinck JE, Schmitt CJ, Ellersieck MR, Tillitt DE. Relations between and among contaminant concentrations and biomarkers in black bass (Micropterus spp.) and common carp (Cyprinus carpio) from large U.S. rivers, 1995-2004. J Environ Monit 2008; 10:1499-518.

Hinck JE, Schmitt CJ, Chojnacki KA, Tillitt DE. Environmental contaminants in freshwater fish and their risk to piscivorous wildlife based on a national monitoring program. Environ Monit Assess 2009;152:469-94.

Lazorchak JM, McCormick FH, Henry TR, Herlihy AT. Contamination of fish in streams of the mid-Atlantic region: an approach to regional indicator selection and wildlife assessment. Environ Toxicol Chem 2003;22:545-53.

Lazorchak JM, Emery EB, Walters DM, McCormick FH, Wesselman R, Hughes RM, et al. Fish tissue contaminants. In: Angradi TR, editor. Great river ecosystems field operations manual. Washington, D.C.: U.S. Environmental Protection Agency, Office of Research and Development; 2006. p. 177-85.

Manchester-Neesvig JB, Valters K, Sonzogni WC Comparison of polybrominated diphenyl ethers (PBDEs) and polychlorinated biphenyls (PCBs) in Lake Michigan salmonids. Environ Sci Technol 2001;35:1072-7.

McDonald M, Blair R, Bolgrien D, Brown B, Dlugosz J, Hale S, et al. The U.S. Environmental Protection Agency's environmental monitoring and assessment program. In: Wiersma GB, editor. Environmental monitoring. New York: CRC; 2004 p. 649-68.

Myers RH. Classical and modern regression with applications. Belmont, California: Duxbury Press; 1990

Neter J, Kutner MH, Nachtsheim CJ, Wasserman W. Applied linear statistical models. Boston, Massachusetts: WCB McGraw-Hill; 1996.

Newman MC, Unger MA. Fundamentals of ecotoxicology. Boca Raton, Florida: Lewis Publishers; 2003.

ORSANCO. Ohio River fish tissue contamination annual report. Cincinnati, OH: Ohio River Valley Water Sanitation Commission; 2004. p. 30.

Peterson SA, Van Sickle J, Herlihy AT, Hughes RM. Mercury contamination in fish from streams and rivers throughout the western United States. Environ Sci Techno 2007; 41:58-65.
Pflieger WL. The fishes of Missouri. Jefferson City, MO: Missouri Department of Conservation; 1975

Rahman F, Langford KH, Scrimshaw MD, Lester JN. Polybrominated diphenyl ether (PBDE) flame retardants. Sci Total Environ 2001;275:1-17.

Rice CP, Chernyak SM, Begnoche L, Quintal R, Hickey J. Comparisons of PBDE composition and concentration in fish collected from the Detroit River, MI and Des Plaines River, IL. Chemosphere 2002;49:731-7.

Schmitt CJ. Organochlorine chemical residues in fish from the Mississippi River basin, 1995. Arch Environ Contam Toxicol 2002;43:81-97.

Schmitt CJ, Zajicek JL, May TW, Cowman DF. Organochlorine residues and elemental contaminants in US freshwater fish, 1976-1986: National Contaminant Biomonitoring Program. Rev Environ Contam Toxicol 1999;162:43-104.

Schwindt AR, Fournie JW, Landers DH, Schreck CB, Kent ML. Mercury concentrations in salmonids from western U.S. national parks and relationships with age and macrophage aggregates. Environ Sci Technol 2008;42:1365-70.

Sethajintanin D, Johnson ER, Loper BR, Anderson KA. Bioaccumulation profiles of chemical contaminants in fish from the Lower Willamette River, Portland Harbor, Oregon. Arch Environ Contam Toxicol 2004;46:114-23.

Stahl LL, Snyder BD, Olsen AR, Pitt JL. Contaminants in fish tissue from US lakes and reservoirs: a national probabilistic study. Environ Monit Assess 2009;150:3-19.

Stevens Jr DL. Variable density grid-based sampling designs for continuous spatial populations. Environmetrics 1997;8:167-95.

Stoddard JL, Peck DV, Olsen AR, Larsen DP, Van Sickle J, Hawkins CP, et al. Environmental Monitoring and Assessment Program (EMAP): western streams and rivers statistical summary. Washington, D.C.: U.S. Environmental Protection Agency, Office of Research and Development; 2005.

Trautman MB. The fishes of Ohio. Columbus, OH: Ohio State University Press; 1981.

USEPA. Great Lakes water quality initiative: technical support document for wildlife criteria. Washington, D.C.: U.S. Environmental Protection Agency, Office of Science and Technology and Office of Water; 1995.

USEPA. Guidance for assessing chemical contaminant data for use in fish advisories. 3rd edition. Washington, D.C.: U.S. Environmental Protection Agency, Office of Water; 2000.

van Boxtel AL, Kamstra JH, Cenijn PH, Pieterse B, Wagner MJ, Antink M, et al. Microarray analysis reveals a mechanism of phenolic polybrominated diphenylether toxicity in zebrafish. Environ Sci Technol 2008;42:1773-9.

Watanabe KH, Desimone FW, Thiyagarajah A, Hartley WR, Hindrichs AE. Fish tissue quality in the lower Mississippi River and health risks from fish consumption. Sci Total Environ 2003;302:109-26.

White D, Johnston K, Miller M. Ohio River basin. In: Benke AC, Cushing CE, editors. Rivers of North America. Burlington, Massachusetts: Elsevier Academic Press; 2005. p. 375-424.

Xia K, Luo MB, Lusk C, Armbrust K, Skinner L, Sloan R. Polybrominated diphenyl ethers (PBDEs) in biota representing different trophic levels of the Hudson River, New York: from 1999 to 2005. Environ Sci Technol 2008;42:4331-7. 